\title{
Extended-spectrum $\beta$-lactamases producing multidrug resistance Escherichia coli, Salmonella and Klebsiella pneumoniae in pig population of Assam and Meghalaya, India
}

\author{
A. Lalruatdiki, T. K. Dutta, P. Roychoudhury and P. K. Subudhi \\ Department of Veterinary Microbiology, College of Veterinary Science and A.H., Central Agricultural University, Selesih, \\ Aizawl - 796 014, Mizoram, India. \\ Corresponding author: T. K. Dutta, e-mail: tapandutta@rediffmail.com \\ Co-authors: AL: amylr14@gmail.com, PR: parimal74@rediffmail.com, PKS: subudhipk@gmail.com \\ Received: 19-02-2018, Accepted: 16-05-2018, Published online: 29-06-2018
}

doi: 10.14202/vetworld.2018.868-873 How to cite this article: Lalruatdiki A, Dutta TK, Roychoudhury P, Subudhi PK (2018) Extended-spectrum $\beta$-lactamases producing multidrug resistance Escherichia coli, Salmonella and Klebsiella pneumoniae in pig population of Assam and Meghalaya, India, Veterinary World, 11(6): 868-873.

\begin{abstract}
Aim: The present study was conducted to record the prevalence of extended spectrum $\beta$-lactamases (ESBLs) producing Escherichia coli, Salmonella spp., and Klebsiella pneumoniae from pig population of Assam and Meghalaya and to record the ability of the resistant bacteria to transfer the resistance genes horizontally.

Materials and Methods: Fecal samples ( $\mathrm{n}=228)$, collected from pigs of Assam (n=99) and Meghalaya (n=129), were processed for isolation and identification of E. coli and Salmonella spp. All the isolates were tested for ESBLs production by double disc synergy test (DDST) followed by screening for ESBLs producing genes ( $b l a_{\mathrm{TEM}}, b l a_{\mathrm{SHV}}, b l a_{\mathrm{CTX}-\mathrm{M}}$, and $\left.b l a_{\mathrm{CMY}}\right)$ by polymerase chain reaction (PCR). Possible transfer of resistance encoding genes between enteric bacterial species was carried out by in vitro and in vivo horizontal gene transfer (HGT) method.

Results: A total of 897 enteric bacteria (867 E. coli and 30 Salmonella) were isolated and identified. Altogether $25.41 \%$ isolates were confirmed as ESBL producers by DDST method. Majority of the isolates were E. coli followed by Salmonella. By PCR, 9.03\% isolates were found positive for at least one of the target resistance genes. $b l a_{\mathrm{SHV}}$ was absent in all the isolates. $b l a_{\mathrm{CMY}}$ was the most prevalent gene. All the $E$. coli isolates from Assam were negative for $b l a_{\mathrm{TEM}}$. A total of $2.76 \%$ isolates were positive for $b l a_{\mathrm{TEM}}+b l a_{\mathrm{CMY}}$ On the other hand, $0.67 \%$ isolates were positive for $b l a_{\mathrm{CTX}-\mathrm{M}}+b l a_{\mathrm{CMY}}$ genes. Only $0.33 \%$ isolates carried all the three genes. Altogether, $4.68 \%$ bacteria carried the resistance encoding genes in their plasmids. bla $_{\text {TEM }}$ gene could be successfully transferred from Salmonella (donor) to E. coli (recipient) by in vitro $\left(5.5-5.7 \times 10^{-5}\right)$ and in vivo $\left(6.5 \times 10^{-5}\right.$ to $\left.8.8 \times 10^{-4}\right)$ methods. In vivo method was more effective than in vitro in the transfer of resistance genes.

Conclusion: The pig population of Assam and Meghalaya are carrying multidrug resistance and ESBLs producing E. coli and Salmonella. The isolates are also capable to transfer their resistance trait to other bacterial species by HGT. The present finding could be considered as a serious public health concern as similar trait can also be transmitted to the human commensal bacteria as well as pathogens.
\end{abstract}

Keywords: Enterobacteriaceae, multidrug resistance, North East India, pigs.

\section{Introduction}

In large-scale poultry and livestock production facilities, antimicrobial agents may be used for therapeutic, prophylactic, and/or sub-therapeutic growth promotion purposes. Such use of antimicrobial agents puts selective pressure on commensals and pathogenic bacteria contributing to the clonal expansion of multidrug-resistant (MDR) bacteria [1]. The use of antibiotics in farm animals that are critically important in human medicine is implicated in the emergence of new forms of MDR bacteria particularly the bacterial species under family Enterobacteriaceae. The problem of MDR is a major public health concern due to its global dimension

Copyright: Lalruatdiki, et al. Open Access. This article is distributed under the terms of the Creative Commons Attribution 4.0 International License (http://creativecommons.org/licenses/ by/4.0/), which permits unrestricted use, distribution, and reproduction in any medium, provided you give appropriate credit to the original author(s) and the source, provide a link to the Creative Commons license, and indicate if changes were made. The Creative Commons Public Domain Dedication waiver (http:// creativecommons.org/publicdomain/zero/1.0/) applies to the data made available in this article, unless otherwise stated. and alarming magnitude, although the epidemiology of resistance can exhibit a remarkable geographical variability and a rapid temporal evolution [2]. The rapid emergence of extended spectrum $\beta$-lactamases (ESBLs) made a serious impact on the treatment and therapeutic strategy of clinical infections [3] mainly caused by the enteric bacteria, namely Escherichia coli, Salmonella spp., and Klebsiella pneumoniae.

Food animals, including pigs, are one of the most important sources of development of MDR bacteria because of continuous use of antibiotics as feed additives and growth promoting factors at a sub-therapeutic level [4]. This practice may lead to the selection of a resistant population in the native microbiota of the animal and the local environment due to shedding through feces. The MDR bacteria may re-enter the human and animal populations through various routes including natural water, irrigation water, drinking water, vegetables, and foods.

Although a handful of sporadic report on MDR enteric bacteria of animal origin from different parts 
of India is available, so far, very little is known about the MDR bacteria in pigs of Northeastern region of India [5]. The present study was undertaken to record the prevalence of ESBLs producing E. coli, Salmonella spp., and K. pneumoniae from pig population of Assam and Meghalaya and to record the ability of the resistant bacteria to transfer the resistance genes horizontally.

\section{Materials and Methods}

\section{Ethical approval}

The animal experimentation was approved by The Institutional Animal Ethics Committee, College of Veterinary Science \& A.H., CAU, Aizawl, Mizoram and all samples were collected by skilled personnel without any harm to the animals.

\section{Sampling and isolation of bacteria}

A total of 228 fecal samples of pigs from Assam $(n=99)$ and Meghalaya $(n=129)$ were collected irrespective of their sex, age, or breed. All the samples were processed for isolation and identification of E. coli, Salmonella spp., and K. pneumoniae by standard bacteriological techniques.

\section{Antimicrobial sensitivity and detection of ESBLs pro- duction by the phenotypic method}

All the isolates were processed for antimicrobial susceptibility test on Mueller-Hinton agar plate as per the recommendation of Clinical Laboratory Standard Institute (CLSI) [6] using commercially available antibiotic disks, namely ceftriaxone, ceftazidime, cefixime, cefotaxime, ampicillin, cefalexin, gentamicin, ciprofloxacin, piperacillin, amoxicillin, imipenem, aztreonam, streptomycin, and nalidixic acid. Isolates showing resistance to the third generation cephalosporins were subjected to double disc synergy test (DDST) by placing cefotaxime and cefotaxime/ clavulanate, amoxicillin and amoxicillin/clavulanate, and ceftazidime and ceftazidime/clavulanate disks in each plate of Mueller-Hinton agar at a distance of $25 \mathrm{~mm}$ apart as per the recommendation of CLSI [6]. Plates were incubated overnight, and the increase in zone size more than $5 \mathrm{~mm}$ was considered as positive for ESBLs production.

\section{Extraction of plasmid and chromosomal DNA}

Plasmid DNA and chromosomal DNA were extracted from all the isolates found to be positive for ESBLs using modified alkaline lysis method.

\section{Polymerase chain reaction (PCR) detection of selected ESBLs producing genes}

All the suspected ESBLs producing isolates were subjected to PCR for detection of ESBLs producing genes ( $b l a_{\mathrm{TEM}}, b l a_{\mathrm{SHV}}, b l a_{\mathrm{CTX}-\mathrm{M}}$, and $\left.b l a_{\mathrm{CMY}}\right)$ using specific primers [5]. PCR was carried out in a $0.2 \mathrm{ml}$ thin wall PCR tubes with a final volume of $25 \mu 1$ containing $10 \times$ buffer, $1.5 \mathrm{mM} \mathrm{MgCl}_{2}, 200 \mathrm{pM}$ of each oligonucleotide primers, $200 \mu \mathrm{M}$ of each dNTPs, $1 \mathrm{U}$ of Taq polymerase, and $50 \mathrm{pg}$ DNA. The reaction was carried out in a thermal cycler (Mastercycler Nexus
Gradient, Eppendorf, Germany) using the following temperature regimes: Initial denaturation at $94^{\circ} \mathrm{C}$ for 5 min followed by 30 cycles of amplification with denaturation at $94^{\circ} \mathrm{C}$ for $30 \mathrm{~s}$ (SHV and TEM), $94^{\circ} \mathrm{C}$ for $45 \mathrm{~s}$ (CMY and CTX-M); annealing at $58^{\circ} \mathrm{C}$ for 30 $\mathrm{s}$ (SHV and TEM), $60^{\circ} \mathrm{C}$ for $45 \mathrm{~s}(\mathrm{CMY})$, and $53^{\circ} \mathrm{C}$ for $45 \mathrm{~s}$ (CTX-M); and extension at $72^{\circ} \mathrm{C}$ for $1 \mathrm{~min}$ with final extension at $72^{\circ} \mathrm{C}$ for $6 \mathrm{~min}$. PCR was carried out for all the four genes separately using genomic DNA and plasmid DNA to locate the target genes.

\section{Curing of plasmid}

All the isolates carrying selected ESBLs genes in their plasmid were subjected to curing using acridine orange as per the method described by Silhavy et al. [7]. In brief, $0.2 \mathrm{ml}$ of overnight culture was added in $5 \mathrm{ml}$ LB broth containing different concentrations and incubated overnight at $37^{\circ} \mathrm{C}$ in shaking incubator. Positive control contained only cells with no acridine orange, while negative control contained only acridine orange without cells in LB broth. Next day, the tubes containing the highest concentration of acridine orange showing growth were selected, and loopful of the culture was streaked on MLA plate and incubated at $37^{\circ} \mathrm{C}$ overnight. Colonies from the plates were then checked for the loss of antibiotic resistance by disc diffusion method.

\section{Selection of donor and recipient organism}

Salmonella (DS-54) isolates with the antibiotic resistance pattern of amoxicillin, aztreonam, cefixime, cefotaxime, ceftazidime, ceftriaxone, cephalexin, and streptomycin was studied for the presence of target resistance genes $\left(b l a_{\mathrm{TEM}}, b l a_{\mathrm{CTX}-\mathrm{M}}\right.$, and $\left.b l a_{\mathrm{CMY}}\right)$. The isolate was found to be positive for $b l a_{\mathrm{TEM}}$ and $b l a_{\mathrm{CMY}}$ genes in its plasmids were selected as donor strain. E. coli (DEC-17) was used as recipient strain, which was sensitive to nalidixic acid, ceftazidime, ceftriaxone, cefotaxime, and streptomycin and was also negative for $b l a_{\mathrm{TEM}}$ and $b l a_{\mathrm{CMY}}$ genes in their plasmid as confirmed by PCR analysis.

\section{In vitro horizontal gene transfer (HGT)}

In vitro HGT was performed by broth mating, filter paper mating, and plate mating methods. In broth mating [8] cultures of recipient and donor strains were inoculated separately in LB broth and incubated overnight at $37^{\circ} \mathrm{C}$ and a $1: 2$ ratio (donor to recipient) of the culture was inoculated into fresh LB broth and incubated for $3 \mathrm{~h}$ at $37^{\circ} \mathrm{C}$ in a shaking incubator. Samples $(0.1 \mathrm{ml})$ of this mixture were spread onto the surface of Hektoen enteric agar (HEA) plates containing streptomycin. In filter paper mating donor and recipient bacteria were grown in LB broth to logarithmic phase at $37^{\circ} \mathrm{C}$ and a $1: 4$ ratio (v/v) of the donor and recipient culture were collected on a sterile filter paper. The filter paper containing both the bacteria placed on HEA and incubated at $37^{\circ} \mathrm{C}$ for $20 \mathrm{~h}$. In case of plate mating, the donor and recipient isolates were grown separately on HEA plates containing streptomycin and incubated overnight at $37^{\circ} \mathrm{C}$. Colonies appearing 
in the cross area were pooled and spread on separate HEA containing streptomycin and cefixime. Donor and recipient strains were grown separately in antibiotic-free medium as well as in antibiotic medium as a control. E. coli colonies grown on the selection plates were subjected to DDST to confirm the presence of ESBL transconjugants. The frequency of transfer was expressed relative to the number of donor cells. Selected transconjugants (E. coli) were further characterized for their antimicrobial susceptibility, ESBL phenotype, plasmid profiling, and the presence of $b l a_{\mathrm{TEM}}$ and $b l a_{\mathrm{CMY}}$ genes by PCR.

\section{In vivo mating}

In vivo mating experiment was performed using mouse model. The mating experiment was performed with and without any antibiotic pressure. 6-8 weeks old, outbred Swiss albino mice were used for colonization and antimicrobial resistance transfer studies. A total of 6 mice were used for the experiment. Mouse numbers M1, M2, and M3 were grouped under antibiotic treatment, whereas mouse numbers M4, M5, and M6 were grouped under non-antibiotic treatment. The mice were individually caged, and cages were changed daily. The mice had unlimited access to food and continuously received either pure drinking water (M4, M5, and M6) or water containing streptomycin sulfate $(0.5 \mathrm{~g} / \mathrm{L})(\mathrm{M} 1, \mathrm{M} 2$, and M3) throughout the study. Before inoculation of the donor or recipient strains, fecal samples from each mouse were tested for the presence of indigenous bacteria with similar resistance. All the six mice were fed with the recipient strain E. coli (DEC-17) $\left(2 \times 10^{9} \mathrm{cfu} / \mathrm{mouse}\right)$ per os. The numbers of c.f.u. in fecal samples were determined on HEA plates containing $14 \mathrm{mg} / \mathrm{ml}$ streptomycin. On the $7^{\text {th }}$ day, the donor strain Salmonella sp. (DS54) was fed at $2 \times 10^{9} \mathrm{cfu} /$ mouse per os. Fecal samples were collected from each mouse on days $2,4,6,8$, and 10 postinoculation. The samples were processed for detection of donor, recipient, and transconjugants on selective medium. Frequency of the transfer of resistance genes from donor to recipient strains was determined by the ratio of transconjugants and donor. Selected transconjugants (E. coli) were further characterized for their antimicrobial susceptibility, ESBL phenotype, plasmid profiling, and the presence of bla $_{\mathrm{TEM}}$ and $b l a_{\mathrm{CMY}}$ genes by PCR.

\section{Determination of minimal inhibitory concentration (MIC) by agar plate dilution method}

MIC was determined only to those isolates, which were used for conjugation study. Isolate number DS-54 was used as donor and isolate number DEC-17 was used as a recipient for determining their MIC using streptomycin.

\section{Results}

\section{Bacterial isolates}

A total of 897 enteric bacteria $(867$ E. coli and 30 Salmonella) were isolated from 228 fecal samples of pigs. Of the $867(96.65 \%)$ E. coli isolates, 537 were from Meghalaya, and 330 were from Assam. Similarly, of the 30 (3.34\%) Salmonella spp. isolates, 24 were from Meghalaya and 6 were from Assam. $K$. pneumoniae could not be isolated from any samples under the study.

\section{Phenotypic detection of ESBLs production}

Based on the observation of antimicrobial sensitivity assay, a total of $450(50.16 \%)$ isolates were found to be positive and suspected for ESBL production, of which $429(49.48 \%)$ were E. coli (216 from Meghalaya and 213 from Assam) and 21 (70.00\%) were Salmonella spp. (15 from Meghalaya and 6 from Assam). Of the 450 isolates, 228 (25.41\%) were confirmed as ESBL producers based on the DDST screening method. Of the 228 ESBLs producing isolates, $210(24.22 \%)$ and $18(60.00 \%)$ were E. coli and Salmonella spp., respectively.

\section{Genotypic characterization of ESBLs production}

Of the 210 ESBL producing E. coli isolates confirmed by DDST method, 66 (7.61\%) were found to be positive for at least one of the three ESBLs gene, namely $b l a_{\mathrm{TEM}}(918 \mathrm{bp}), b l a_{\text {СТХ-M }}(540 \mathrm{bp})$, and $b l a_{\mathrm{CMY}}$ (462 bp) (Table-1, Figures-1 and 2). Of the 66 isolates, $15(1.73 \%), 9(1.03 \%)$, and $24(2.76 \%)$ were found to be positive for $b l a_{\mathrm{TEM}}, b l a_{\mathrm{CTX}-\mathrm{M}}$, and $b l a_{\mathrm{CMY}}$, respectively (Table-1). A total of $15(1.73 \%)$ and $3(0.90 \%)$ isolates were positive for combination of $b l a_{\mathrm{TEM}}+$ $b l a_{\mathrm{CMY}}$ and $b l a_{\mathrm{CTX}-\mathrm{M}}+b l a_{\mathrm{CMY}}$ genes, respectively. Similarly, of the 21 Salmonella isolates, 12 were positive for at least one of the three ESBLs gene (Table-1), of which $3(10.00 \%)$ isolates were positive for $b l a_{\mathrm{CMY}}$ gene. A total of $6(20.00 \%)$ and $3(10.00 \%)$ isolates were positive for combination of $b l a_{\mathrm{TEM}}+b l a_{\mathrm{CMY}}$ and $b l a_{\text {СТX-M }}+b l a_{\mathrm{TEM}}+b l a_{\mathrm{CMY}}$ genes, respectively.

\section{In vitro HGT}

Transconjugants were detected only in broth mating and filter paper mating methods. The isolated

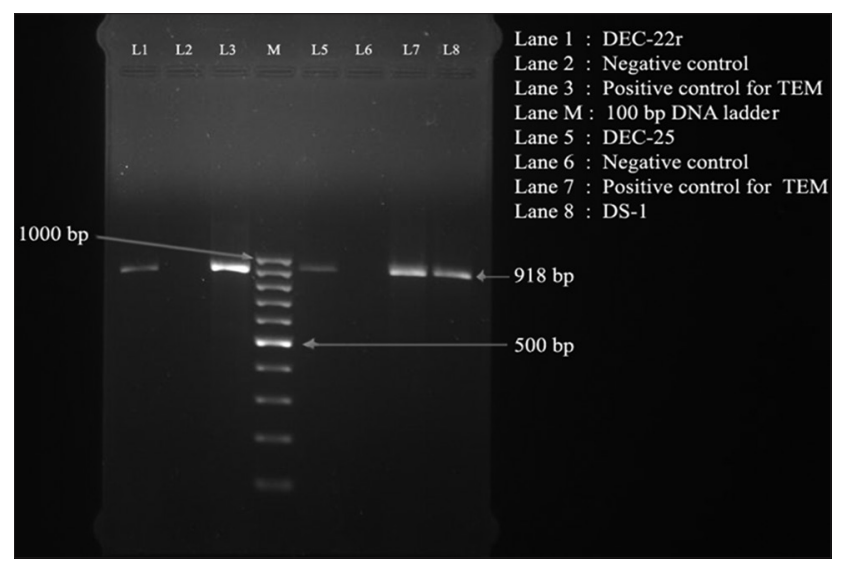

Figure-1: Polymerase chain reaction assay for detection of bla $_{\text {TEM }}$ gene (918 bp) in Escherichia coli isolated from pigs of NER starts of India. Lane 1: DEC-22; Lane 2: Negative control; Lane 3: Positive control for TEM; Lane M: 100 bp DNA ladder; Lane 5: DEC-25; Lane 6: Negative control; Lane 7: Positive control for TEM; and Lane 8: DS-1. 
transconjugants showed identical resistance profiles and all contained in a large plasmid. Only $b l a_{\text {TEM }}$ gene could be transferred from the donor to recipient in the absence of antibiotic pressure. The target gene was detected from the transconjugants obtained from the plate, whereas it was absent in recipient strain,

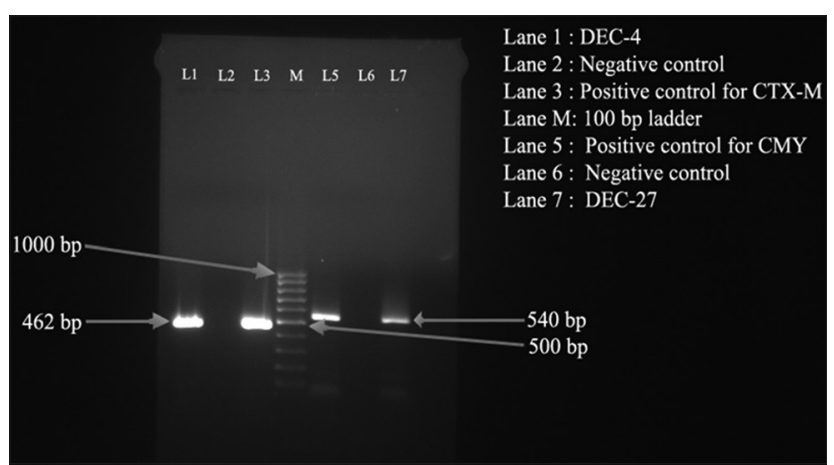

Figure-2: Polymerase chain reaction-based detection of bla $_{\text {СтХ-м }}\left(462 \mathrm{bp}\right.$ ) and bla ${ }_{\text {СмY }}(540 \mathrm{bp})$ genes Escherichia coli isolated from pigs of NER starts of India. Lane 1: DEC-4; Lane 2: Negative control; Lane 3: Positive control for CTXM; Lane M: 100 bp DNA ladder; Lane 5: Positive control for CMY; Lane 6: Negative control; and Lane 7: DEC-27.

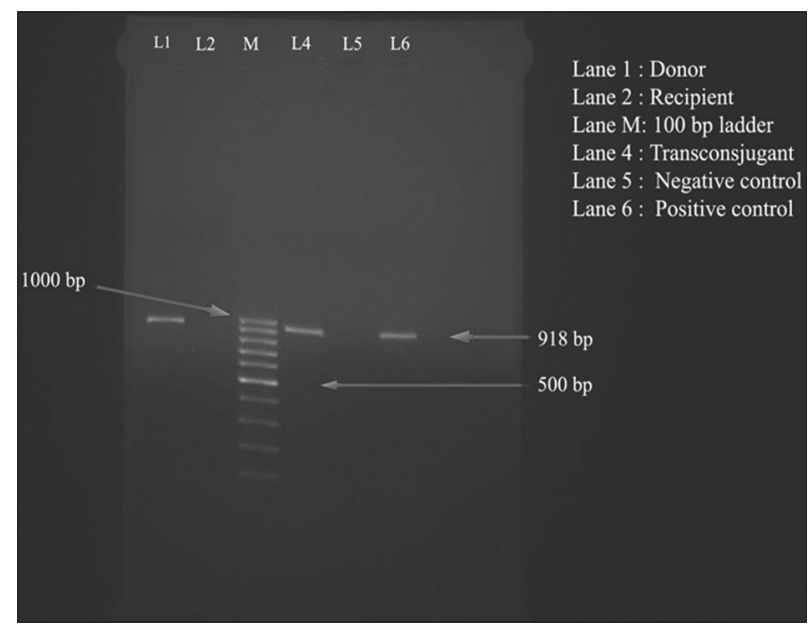

Figure-3: Polymerase chain reaction assay for detection of (bla $a_{\mathrm{TEM}}$ ) gene (918 bp) in transconjugant for confirmation of horizontal gene transfer conjugation. Lane 1: Donor; Lane 2: Recipient; Lane M: 100 bp DNA ladder; Lane 4: Transconjugant; Lane 5: Negative control; and Lane 6: Positive control. as detected by PCR assay (Figure-3). The resistance plasmid transfer rate from donor to the recipient was $5.5 \times 10^{-5}$ in filter paper mating and $5.7 \times 10^{-5}$ by broth mating in respect to the recipient.

\section{In vivo HGT}

Transconjugants were obtained from both the experimental groups and were resistant to streptomycin and carrying plasmids with $b l a_{\text {TEM }}$ gene (Figure-3). The frequency of transconjugants from antibiotic treatment group $\left(8.8 \times 10^{-4}\right)$ was higher than the non-antibiotic group $\left(6.5 \times 10^{-5}\right)$. Transconjugants were detected from the mouse with antibiotic treatment group from the $4^{\text {th }}$-day postinoculation, whereas, it could be detected from the $6^{\text {th }}$-day postinoculation from the group without any antibiotic pressure.

\section{Discussion}

The present study revealed that the prevalence of bla ${ }_{\mathrm{CMY}}$ gene in $E$. coli was highest in both the states compared to the other two genes. bla $a_{\mathrm{CMY}}$ is the member of the plasmid-mediated AmpC like enzyme, which has been shown to be the most common gene associated with ceftriaxone resistance among E. coli and Salmonella serovars in food animals and humans [9]. Detection of bla ${ }_{\mathrm{CMY}}$ in pigs also reported by Mandakini [8] from India in feces of animals, particularly pigs by various workers abroad with nearly similar kind of result [10].

$b l a_{\text {TEM }}$ gene was only recorded in E. coli from Meghalaya, whereas all the $E$. coli isolates from Assam were recorded as negative. Similarly, Salmonella isolates from Meghalaya and Assam were recorded as positive for $b l a_{\text {TEM }}$ gene. Lalzampuia et al. [11] reported from the same laboratory that none of the 102 E. coli isolates from pigs in Mizoram were carrying $b l a_{\mathrm{TEM}}$ gene. The $b l a_{\text {TEM }}$ genes also have a tendency to mutate and secrete enzymes with extended spectrum of activity, which could have accounted for the high resistance to ampicillin in the population studied [12].

Similarly, the population of bla $a_{\text {CTX-M }}$ gene positive in E. coli was higher in Assam compared to Meghalaya. In contrast to that Salmonella isolates carrying bla ${ }_{\text {СТХ-м }}$ gene from both the states were nearly similar. In comparison to $b l a_{\mathrm{TEM}}$ and $b l a_{\mathrm{CMY}}$ genes,

Table-1: Distribution of bla genes ( $b / a_{\mathrm{TEM}^{\prime}} b / a_{\mathrm{CTX}_{\mathrm{M}} \mathrm{M}^{\prime}}$ and $\left.b / a_{\mathrm{CMY}}\right)$ in E. coli and Salmonella spp. Isolated form pigs in Meghalaya and Assam.

\begin{tabular}{|c|c|c|c|c|c|c|}
\hline \multirow[t]{2}{*}{ Genes } & \multicolumn{3}{|c|}{ E. coli $(\%)$} & \multicolumn{3}{|c|}{ Salmonella (\%) } \\
\hline & Meghalaya & Assam & Total & Meghalaya & Assam & Total \\
\hline$b^{b} a_{\mathrm{TEM}}$ & $15(2.79)$ & 0.00 & $15(1.73)$ & 0.00 & 0.00 & 0.00 \\
\hline bla & $3(0.55)$ & $6(1.01)$ & $9(1.03)$ & 0.00 & 0.00 & 0.00 \\
\hline bla & $21(3.91)$ & $3(0.90)$ & $24(2.76)$ & $3(12.50)$ & 0.00 & $3(10.00)$ \\
\hline$b / a_{\mathrm{TEM}}$ and $b / a_{\mathrm{CTX}-\mathrm{M}}$ & 0.00 & 0.00 & 0.00 & 0.00 & 0.00 & 0.00 \\
\hline bla $a_{\mathrm{TEM}}$ and bla & $15(2.79)$ & 0.00 & $15(1.73)$ & $3(12.50)$ & $3(50.00)$ & $6(20.00)$ \\
\hline bla $a_{\mathrm{CTX}-\mathrm{M}}$ and bla & 0.00 & $3(0.90)$ & $3(0.34)$ & 0.00 & 0.00 & 0.00 \\
\hline bla $_{\text {TEM }}$ bla ${ }_{\text {CTX-M }}$ and bla $a_{\text {CMY }}$ & 0.00 & 0.00 & 0.00 & $3(12.50)$ & 0.00 & $3(10.00)$ \\
\hline
\end{tabular}

Figures in parenthesis are percentile values 
the prevalence of bla ${ }_{\text {Стх-м }}$ gene in both E. coli and Salmonella from Meghalaya and Assam was found to be lower. Our result is also in corroboration with the report of other workers [13-15].

In this study, DS-54 was successfully cured using acridine orange at a concentration of $2-2.5 \mathrm{mg} / \mathrm{ml}$. Akortha and Filgona [16] used $0.10 \mathrm{mg} / \mathrm{ml}$ of acridine orange for plasmid curing of E. coli isolates. Although curing provides only the preliminary evidence that genetic traits are of extrachromosomal nature, the loss of growth on antibiotic containing plates shows that the multidrug resistance genes may be plasmid-borne. It is, however, important to note that all antibiotic resistance genes are plasmid mediated [17]. Sometimes copies of the plasmids lying closer to the membrane are eliminated by curing agents, while those lying closer to the nucleus may escape the curing effect [18].

During the HGT study, the plasmids carrying $b l a_{\mathrm{TEM}}$ gene could be transferred horizontally to the recipient isolates only by broth mating and filter paper mating. The resistance gene was not transferred in plate mating. The resistance plasmid transfer rate from donor to the recipient by broth mating was $5.7 \times 10^{-5} /$ recipient, whereas in filter plate mating it was $5.5 \times 10^{-5} /$ recipient. Faure et al. [15] reported the mean frequency of transfer of resistance plasmid from Salmonella to E. coli at 5.9 to $5.7 \times 10^{-8}$ /donor. The frequency of the transfer of resistance plasmids from donor to the recipient may vary depending on the copy number of the conjugative plasmids in the donor strain.

Similarly, in in vivo experiment using mice model the frequency of transfer of conjugative plasmid carrying antibiotic resistance genes increased in the presence of antibiotic selection pressure. There was negligible difference in the frequencies of transfer of the plasmids from donor to recipient $\left(5.7 \times 10^{-5} \mathrm{vs}\right.$ $6.5 \times 10^{-5} /$ recipient. However, the frequency of transfer of the target plasmid was significantly increased $\left(8.8 \times 10^{-4}\right)$ in the presence of antibiotic selection pressure in mice model. Similar kinds of the report are also published by several workers from abroad $[14,15]$. In vitro experiment showed the transfer of the plasmids ranging from 108 to $157 \mathrm{~kb}$, while in vivo conjugation experiment showed a transfer of smaller sized plasmids [19].

In this study, only $b l a_{\text {TEM }}$ gene could be transferred from the donor to recipient strain both by in vivo method of HGT. Transfer of bla $a_{\mathrm{TEM}}$ gene carrying plasmid from donor to recipient in the presence of streptomycin is also reported by Chen et al. [20]. $b l a_{\text {TEM }}$ is associated with plasmid-mediated beta-lactamase, which confers resistance to the third generation of cephalosporins, particularly ceftazidime, and cefotaxime [21]. bla $\mathrm{TEM}$ beta-lactamases are maintained the ability of the bacteria to hydrolyze third-generation cephalosporins but also demonstrate an inhibitor resistance [21].

\section{Conclusion}

This study showed that the ESBL producing genes $\left(b l a_{\mathrm{TEM}}, b l a_{\mathrm{CTX}-\mathrm{M}}\right.$, and $\left.b l a_{\mathrm{CMY}}\right)$ are prevalent in the enteric bacteria of pig population in Meghalaya and Assam. Presence of such genes in extrachromosomal component of enteric bacteria indicates their potential to transfer within species or inter-species in animal population in this region. It also needs to understand the different methods of the possible spread of resistant bacterial population in the society to curb the menace of further development of multidrug-resistant bacteria in the environment.

\section{Authors' Contributions}

AL: Collection of samples, processing for isolation and identification of bacteria, in vitro and in vivo HGT assay. TKD: Genesis of concept of the work and preparation of the manuscript. PR: Detection of ESBLs genes by PCR assays. PKS: AMR sensitivity assay and data analysis. All authors read and approved the final manuscript.

\section{Acknowledgments}

The authors are highly thankful to the DBT funded project on ADMaC (Sanction Order No. DBT-NER/LIVS/11/2012 dated 24/04/2014) for providing the necessary funds and the Dean, College of Veterinary Science and A.H., CAU, Aizawl for providing all the facilities to conduct the study.

\section{Competing Interests}

The authors declare that they have no competing interests.

\section{References}

1. Davis, G.S. and Price, L.B. (2016), Recent research examining links among Klebsiella pneumoniae from food, food animals and human extraintestinal infections. Curr. Environ. Health Rep. 3(2): 128-135.

2. Blaak, H., DeKruijf,P., Hamidjaja, R.A., Van Hoek,A.H.A.M., De Roda Husman, A.M. and Schets, F.M. (2014) Prevalence and characteristics of ESBL producing E. coli in Dutch recreational waters influenced by wastewater treatment plants. Vet. Microbiol., 171(3-4): 448-459.

3. Hamilton, W.L. and Wenlock, R. (2016) Antimicrobial resistance: A major threat to public health. http://cambridgemedicine.org/hamilton2016/. Last accessed on 29-04-2018.

4. Rather, I.A., Kim, B.C., Bajpai, V.K. and Park, Y.H. (2017) Self-medication and antibiotic resistance: Crisis, current challenges, and prevention. Saudi. J. Biol. Sci., 24: 808-812.

5. Mandakini, R., Dutta, T.K., Chingtham, S., Roychoudhury, P., Samanta, I., Joardar, S.N., Pachauau, A.R. and Chandra, R. (2014) ESBL-producing Shiga-toxigenic E. coli (STEC) associated with piglet diarrhoea in India. Trop. Anim. Health Prod., 47(2): 377-381.

6. CLSI. (2014) Performance Standards for Antimicrobial Susceptibility Testing, $18^{\text {th }}$ Informational Supplement. M100-S18. Clinical and Laboratory Standards Institute, Wayne, PA.

7. Silhavy, T.J., Berman, M.L. and Enquist, L.W. (1984) Experiments with Gene Fusions. Cold Spring Harbor Laboratory Press, Cold Spring Harbor, New York.

8. Mandakini, R. (2015) Analysis of Multi-Drug Resistance Genes in Escherichia coli Isolates from Pigs of 
North-Eastern India. Ph.D. Thesis, Submitted to Central Agricultural University, Imphal, Manipur, India.

9. Karuppasamy, C., Dutta, T.K., Sharma, I., Mandal, S.D., Senthilkumar, N. and Ralte, L. (2017) Prevalence of multidrug-resistant enteropathogenic and enteroinvasive Escherichia coli isolated from children with and without diarrhea in Northeast Indian Population. Ann. Clin. Microbiol. Antimicrob., 16: 49.

10. Alcaine, S.D., Sukhnanand, S.S., Warnick, L.D., Su, W.L., McGann, P., McDonough, P. and Wiedmann, M. (2005) Ceftiofur-resistant Salmonella strains isolated from dairy farms represent multiple widely distributed subtypes that evolved by independent horizontal gene transfer. Antimicrob. Agents Chemother, 49: 4061-406.

11. Lalzampuia, H., Dutta, T.K., Warjri, I. and Chandra, R. (2013) PCR-based detection of extended-spectrum $\beta$-lactamases $\left(b l a_{\text {СTX-M-1 }}\right.$ and $\left.b l a_{\text {TEM }}\right)$ in Escherichia coli, Salmonella spp. and Klebsiella pneumoniae Isolated from Pigs in North Eastern India (Mizoram). Ind. J. Microbiol., 53(3): 291-296

12. Wandili, S.A., Onyango, D.M. and Waindi, E.N. (2013) Prevalence and antimicrobial resistance profile of clinical Salmonella isolates from Nandi Central of Rift Valley, Kenya. Intl. J. Innov. Biotechnol. Biochem., 1(1): 1-10.

13. Li, W., Huang, F.Y., Liu, C.P., Weng, L.C., Wang, N.Y., Chiu N.C. and Chiang, C.S. (2005) Ceftriaxone resistant of non-typhoidal Salmonella enterica isolates in Northern Taiwan attributable to production of CTX-M-14 and CMY-2 $\beta$-lactamases. J. Clin. Microbiol., 43: 3237-3243.

14. Winokur, P.L., Vonstein, D.L., Hoffman, L.J., Uhlenhopp, E.K. and Doern, G.V. (2001) Evidence for transfer of CMY-2 AmpC $\beta$-Lactamase plasmids between Escherichia coli and Salmonella isolates from food animals and humans. Antimicrob. Agents Chemother. 45: 2716-2722.

15. Faure, S., Guyomard, P.A., Delmas, J.M. and Laurentie, M. (2009) Impact of therapeutic treatment with $\beta$-lactam on transfer of the bla $a_{\text {СтХ-м-9 }}$ resistance gene from Salmonella enterica serovar Virchow to Escherichia coli in gnotobiotic Rats. Appl. Environ. Microbiol., 75: 5523-5528.

16. Akortha, E.E. and Filgona, J. (2009) Transfer of gentamicin resistance genes among Enterobacteriaceae isolated from the outpatients with urinary tract infections attending 3 hospitals in Mubi, Adamawa State. Sci. Res. Essay, 4: 745-752.

17. Shoemaker, N.B., Wang, G.R. and Salyers, A.A. (1992) Evidence for natural transfer of a tetracycline resistance gene between bacteria from the human colon and bacteria from the bovine lumen. Appl. Environ. Microbiol., 58: $1313-1320$.

18. Jenks, P.J., Hu, Y.M., Danel, F., Mehtar, S. and Livermore, D.M. (1995) Plasmid-mediated production of class1 (AmpC) $\beta$-lactamase by two Klebsiella pneumoniae. J. Antimicrob. Chemother, 35: 235-236.

19. Harajly, M., Khairallah, M., Corkill, J.E., Araj, G.F. and Matar, G.M. (2010) Frequency of conjugative transfer of plasmid-encoded ISECP-1-bla $a_{\text {СТХ-M-15 }}$ and $a a c$ (6')-lb-crgenes in Enterobaccteriaceae at a tertiary care centre in Lebanon- Role of transferases. Ann. Clin. Microbiol. Antimicrob., 9: 19-27.

20. Chen, S., Zhao, S., White, D.G., Schroeder, C.M., Lu, R., Yang, H., McDermott, P.F. and Ayers, S. (2004) Characterisation of multiple-antimicrobial-resistant Salmonella serovars isolated from retails meats. Appl. Environ. Microbiol., 70(1): 1-7.

21. Al-Jasser, A.M. (2006) Extended spectrum beta- lactamases (ESBLs): A global problem. Kuwait Med. J. 38: 171-185. 